\title{
Macrobenthic community of an estuarine tidal flat on the Amazon coast: spatial variations and presence of polychaetes tubes
}

\author{
Thuareag Monteiro Trindade dos Santos ${ }^{1,4}$ \& Daiane Aviz ${ }^{2,3,5}$
}

${ }^{1}$ Universidade Federal do Pará (UFPA), Instituto de Geociências, Faculdade de Oceanografia, Laboratório de Pesquisa em Monitoramento Ambiental Marinho (LAPMAR), Grupo de Estudos de Nematoda Aquáticos (GENAQ). Belém, PA, Brasil.

${ }^{2}$ Museu Paraense "Emílio Goeldi" (MPEG), Campus de Pesquisa, Coordenação de Zoologia (COZO0), Laboratório de Invertebrados Aquáticos. Belém, PA, Brasil.

${ }^{3}$ Universidade Federal do Pará (UFPA), Instituto de Geociências, Faculdade de Oceanografia, Laboratório de Oceanografia Biológica (LOB). Belém, PA, Brasil.

${ }^{4}$ ORCID: http://orcid.org/0000-0002-4194-8127. E-mail: thuareag@gmail.com (corresponding author)

${ }^{5}$ ORCID: http://orcid.org/0000-0002-7828-3229. E-mail: daiane.aviz@gmail.com

\begin{abstract}
The present study characterized the macrobenthic fauna found on a muddy-sandy tidal flat of the Amazon coast in areas with and without the presence of Diopatra cuprea (Bosc, 1802) (Onuphidae: Annelida) tubes. In addition, a brief review of records of $D$. cuprea on the Brazilian Amazon coast is presented. Samples were collected in February 2014 in two different areas: (1) an area in which $D$. cuprea tubes were present, and (2) a control area, in which worm tubes were absent. A total of 21 taxa were found, of which 10 were associated exclusively with $D$. cuprea tubes. Although richness did not vary significantly among areas, there were changes in the abundance and composition of species and trophic guilds. In the area with tubes, there was a higher abundance of filter-feeders and the presence of species adapted to consolidated and muddy substrates. Our results and those of other studies indicate that $D$. cuprea commonly presents low density in the Amazon coastal, and its tubes are typically scattered widely in the intertidal zone. The present findings add knowledge about the presence of the bioconstructor in coastal areas and reinforce the role of tube-building polychaetes as ecosystem engineers.
\end{abstract}

Keywords. Diopatra cuprea; Ecosystem engineers; Macrotide; Soft-bottom; Tropical region.

\section{INTRODUCTION}

Numerous marine habitat-formers build external physical structures such as shells or tubes that can provide space and shelter from predators (Giangrande et al., 2020). In soft-bottom habitats, tube-building polychaetes represent an important group of marine organisms that build such external structures. The polychaete tubes can be made from several different materials (e.g., mud, sand, shell, sandstone) and are known to influence near-bed hydrodynamics (Jumars \& Nowell, 1984), stabilizing the sediments (Bolam \& Fernandes, 2003). Moreover, these tubes play an especially important ecological role by providing structures that increase the physical complexity and biodiversity of habitats (Dauer et al., 1982; Bailey-Brock, 1984; Dubois et al., 2002; Thomsen et al., 2011). For these reasons, several tube-building polychaetes are designated as ecosystem engineers: organisms capable of modifying the environment by mechanically transforming materials from one state to another, resulting in marked alterations of the distribution of other species (Jones et al., 1994, 2010).

Diopatra cuprea (Bosc, 1802) is a tubicolous species that occurs in coastal waters between Cape Cod and Brazil (Mangum et al., 1968). This species inhabits protected mud and sand flats from the low-tide line to water up to $80 \mathrm{~m}$, building vertical tubes, which typically penetrate the substratum to a depth of 50-60 cm (Myers, 1972). Overall, the construction of these tubes on soft bottoms may influence the structure of the benthic communities, such as the meiofauna (Bell \& Coen, 1982a, b; Bell \& Woodin, 1984; Bell, 1985; Guilherme et al., 2011) and macrofauna (Woodin, 1978; Thomsen et al., 2011; Santos \& Aviz, 2018), as well as the bacteria (Phillips \& Lovell, 1999; Matsui et al., 2004) and algae (Thomsen, 2004; Thomsen et al., 2009). In general, there is a positive influence on the species richness and abundance of the fauna associated with these tubes (Santos \& Aviz, 2018). 
The literature on the fauna associated with polychaetes tubes is impressive, especially regarding the temperate latitudes where they are widespread (e.g., Woodin, 1978; Bell \& Coen, 1982a, b; Callaway, 2003; Dubois et al., 2006; Thomsen et al., 2011; Jones et al., 2018). However, unlike intertidal habitats at temperate latitudes, there are few studies regarding the fauna associated with polychaetes tubes in tropical regions (e.g., Fournier, 2010; Guilherme et al., 2011; Ataide et al., 2014; Aviz et al., 2018, 2021; Lane-Medeiros et al., 2021). In addition, there is virtually no data from tropical regions, especially for the Amazon coast, about studies regarding the fauna associated with $D$. cuprea tubes, even though this species is common in intertidal estuarine areas and protected beaches of the region (Santos \& Aviz, 2018), thus providing limited information on community structure in Amazon coastal areas. In this region, studies on benthic communities have been limited to record this species, with only one study on the effect of the bioconstructor on local biodiversity (Santos \& Aviz, 2018).

Tidal flats are distributed widely along the world's coastline, typically in association with estuaries or other coastal environments (e.g., lagoons and bays) (Dyer et al., 2000). These environments are formed in areas where there is a sufficient supply of fine-grained sediment and gentle bed slopes (Gao, 2019). In addition, these environments are characterized by relatively strong tidal currents, resulting in high mobility of bed materials (Black et al., 2002; Gao, 2019). The Amazon coastal region is dominated by tidal flat systems that extend for almost $480 \mathrm{~km}$ (Kjerfve \& Lacerda, 1993), and are influenced by unique conditions, such as macrotidal regime ( $>4 \mathrm{~m}$ ), high river discharge, and rainfall regime, the latter characterized by two contrasting periods, which lead to marked salinity variation (Dittmar \& Lara, 2001; Souza-Filho et al., 2009; Pereira et al., 2012). Under such conditions, the intertidal benthic macrofauna of the soft-bottom habitats is known for its remarkable spatial and seasonal variations (Rosa-Filho et al., 2018; Venekey et al., 2019; Danin et al., 2020; Baia et al., 2021).

Therefore, this study aimed to investigate the effects of $D$. cuprea tubes on macrobenthic fauna found on a tidal flat area. The tested hypothesis was that the presence of tubes contributes to the establishment of a macrobenthic assemblage distinct, in terms of composition, abundance and functional structure from that found on sediments with no tubes. In addition, a brief review of records of $D$. cuprea on the Brazilian Amazon coast is presented.

\section{MATERIAL AND METHODS}

\section{Study area}

This study was conducted on a tidal muddy-sandy flat located in the estuary of the Piriá river $\left(00^{\circ} 59^{\prime} 26.11^{\prime \prime} \mathrm{S}\right.$, $46^{\circ} 11^{\prime} 08.73^{\prime \prime} \mathrm{W}$ ) (Fig. 1A) in the city of Vizeu (northeast Pará, Brazil). The Piriá river is part of the Gurupi-Piriá Marine Extractive Reserve and covers an area of 74,081 ha distributed in mangrove ecosystems and marine area (ICMBio, 2010). The Reserve is surrounded by the Araí-

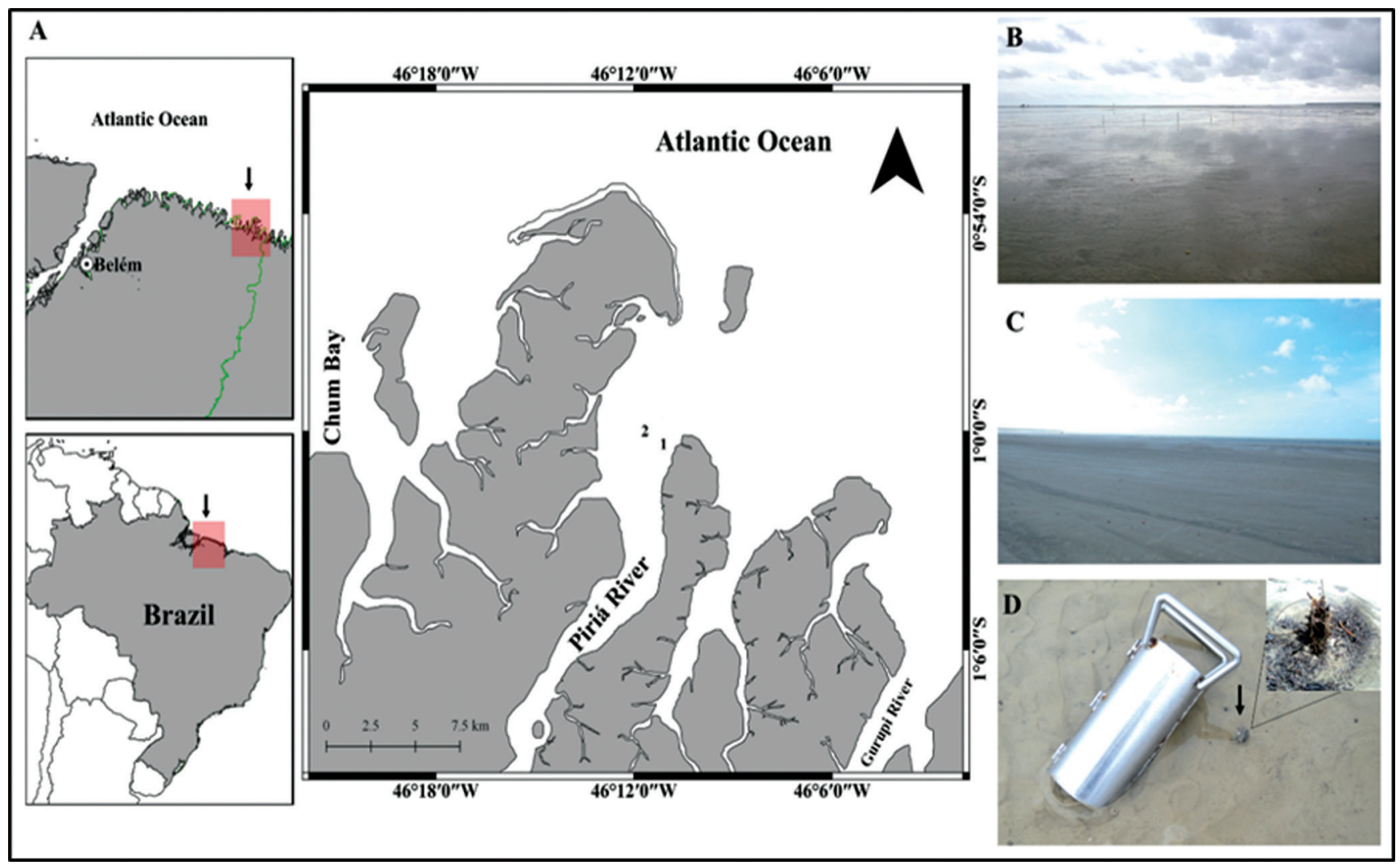

Figure 1. Map of the Piriá river estuary showing the study area (A); Area 1 (B); Area 2 (C); exposed portion of a Diopatra cuprea tube found in the study area and metallic sampler (D). 
Peroba Marine Extractive Reserve to the west and the Reentrâncias Maranhenses Environmental Protection Area in the state of Maranhão to the east.

The region is dominated by semidiurnal macrotides and the amplitude may reach more than $5 \mathrm{~m}$ (Souza-Filho et al., 2009). The climate is humid tropical with a mean annual temperature of $27.7 \pm 1.1^{\circ} \mathrm{C}$ (Martorano et al., 1993) and annual rainfall (30-year series) ranging from 2,200 to 2,800 $\mathrm{mm}$ (Moraes et al., 2005). Rainfall rates vary considerably over the year, with a well-marked rainy season from January to July, with total precipitation of $\sim$ 1,657 $\mathrm{mm}$, and a dry season from August to December, with total rainfall of $490 \mathrm{~mm}$ (Moraes et al., 2005).

\section{Sampling and laboratory procedures}

Samples were collected in February 2014 (rainy season) from two different areas (equidistant $\sim 400 \mathrm{~m}$ ) of the tidal muddy-sandy flat during the low tide, each with an area of $\sim 50 \mathrm{~m}^{2}$, at the same distance from the tideline. One of these areas was populated with $D$. cuprea tubes (area 1) (Fig. 1B), whereas the other had no visible tubes (area 2) (Fig. 1C). Ten replicate samples were collected in each area using cylindrical cores $\left(0.0079 \mathrm{~m}^{2}\right.$, $20 \mathrm{~cm}$ deep) (Fig. 1D). In area 1, the corer was positioned so that a single $D$. cuprea tube (Fig. 1D) stood in its center. The samples were filtered through a $0.3 \mathrm{~mm}$ mesh screen, and all the macrofauna was retrieved and fixed in $4 \%$ saline formalin. To estimate the density of $D$. cuprea within area 1, the number of tubes were counted in five distributed square subplots $\left(25 \mathrm{~m}^{2}\right)$.

In the laboratory, the organisms were examined under a stereoscopic microscope, counted, and identified to the lowest possible taxonomic level based on Amaral \& Nonato (1996), Melo (1999), Amaral et al., (2006), de León-González et al., (2009) and Rios (2009). Macrofauna was further classified into functional groups, considering feeding habits (predator/carnivore, suspensivores, depositive, detritivore and omnivore), based on the primary literature (e.g., Fauchald \& Jumars, 1979; Dauby, et al., 2001; De Broyer et al., 2003; Macdonald et al., 2010). Voucher specimens were deposited in the collections of the Museu Paraense Emílio Goeldi (catalog numbers: MPEG.MOL 003415-003417; MPEG.ANL 002684-002696; MPEG.CRU 003500-003502).

\section{Statistical analysis}

We calculated the total taxon richness and abundance for each biological sample, and, to compare variation in these parameters in areas with and without tubes, the generalized linear models (GLM) based on Poisson distributions was used, appropriate to analyze count data. The GLM was implemented with the package of $\mathrm{R}$ statistical software (version 3.3.0) (Warton et al., 2012). Principal Coordinates Analysis (PCO) was run on a Bray-Curtis similarity matrix of the fourth root-transformed species and functional groups abundance data, to explore and visualize the similarity between samples across areas. To identify the species/functional groups that characterized each area, those correlated (Spearman's coefficient) more than $50 \%$ with one of the first two axes were plotted in each PCO. To test differences in assemblage composition (taxonomic and functional groups) among areas, we applied a permutational multivariate analysis of variance (PERMANOVA), using the same similarity matrix.

\section{RESULTS}

The mean density of $D$. cuprea tubes recorded at area 1 was $37.9 \pm 12.1$ ind. $/ \mathrm{m}^{2}$. Twenty-one macrobenthic taxa (excluding D. cuprea) were recorded during the present study, of which 10 were found exclusively in area 1 (with $D$. cuprea tubes), and three exclusively in area 2 (without tubes) (Table 1). The Annelida (polychaetes) was represented by the largest number of taxa (13) and the most abundant group in both areas (Fig. 2A). Among these, Magelona sp. (13.1\% of total abundance) was the most abundant taxa at area 1, and Nephtys simoni (Perkins, 1980) (18.6\%) and Thoracophelia papillata (Santos, Nonato \& Petersen, 2004) (15.2\%) were the most abundant at area 2. Mollusks (bivalves and gastropods) and arthropods were recorded at higher abundance in area 1. A lower abundance of mollusks was observed in area 2, with an absence of gastropods (Fig. 2A).

Regarding the contribution of the feeding guilds to total abundance, deposit-feeders dominated the trophic web in both areas. However, differences were found in the abundance of the other groups. A higher abundance

Table 1. Mean abundance (ind./ $/ 0.0079 \mathrm{~m}^{2} \pm \mathrm{SE}$ ) of the benthic macrofauna found in the study areas (Area 1: With Diopatra cuprea tubes; Area 2: Without tube) with their trophic group.

\begin{tabular}{lccl}
\hline \multicolumn{1}{c}{ Taxa } & Area 1 & Area 2 & \multicolumn{1}{c}{ Trophic Guild } \\
\hline Nemertea & $0.2 \pm 0.1$ & & Predator \\
Bivalve sp. (B) & $0.1 \pm 0.1 .7$ & & Suspension/filter feeder \\
Mytella guyanensis (B) & $0.3 \pm 0.1$ & & Suspension/filter feeder \\
Donax striatus (B) & $0.4 \pm 0.1$ & $0.3 \pm 0.1$ & Suspension/filter feeder \\
Olivela minuta (G) & $0.3 \pm 0.1$ & & Omnivore \\
Diopatra cuprea (A) & $0.3 \pm 0.1$ & & Omnivore \\
Hemipodia sp. (A) & & $0.4 \pm 0.1$ & Predator/Carnivores \\
Glycera sp. (A) & & $1.6 \pm 0.7$ & Predator/Carnivores \\
Nephtys simoni (A) & $0.4 \pm 0.2$ & $1.1 \pm 0.3$ & Predator/Carnivores \\
Eteone sp. (A) & $0.1 \pm 0.1$ & $0.5 \pm 0.3$ & Predator/Carnivores \\
Thoracophelia papillata (A) & $0.8 \pm 0.4$ & $1.7 \pm 0.7$ & Deposit feeder \\
Armandia sp. (A) & $0.2 \pm 0.2$ & $1.1 \pm 0.4$ & Deposit feeder \\
Sigambra grubii (A) & $0.6 \pm 0.3$ & & Omnivore \\
Scolelepis squamata (A) & $0.1 \pm 0.1$ & $0.8 \pm 0.3$ & Deposit feeder \\
Capitella spp. (A) & $0.7 \pm 0.3$ & & Deposit feeder \\
Mediomastus sp. (A) & $0.3 \pm 0.2$ & & Deposit feeder \\
Nereis sp. (A) & $0.1 \pm 0.1$ & $2.1 \pm 1.2$ & Omnivore \\
Magelona sp. (A) & $0.5 \pm 0.2$ & & Deposit feeder \\
Phoxocephalidae (Cr) & $0.6 \pm 0.4$ & $1.1 \pm 0.5$ & Detritive scavengers \\
Cyprideis sp (Cr) & $0.3 \pm 0.1$ & $0.5 \pm 0.2$ & Suspension/filter feeder \\
Brachyura (Zoea) (Cr) & $0.1 \pm 0.1$ & & - \\
Mysida sp. (Cr) & & $0.2 \pm 0.1$ & Omnivore \\
\hline
\end{tabular}

* Taxa: $A=$ Annelida; $B=$ Bivalvia; $G=$ Gastropoda; $C r=$ Crustacea. 

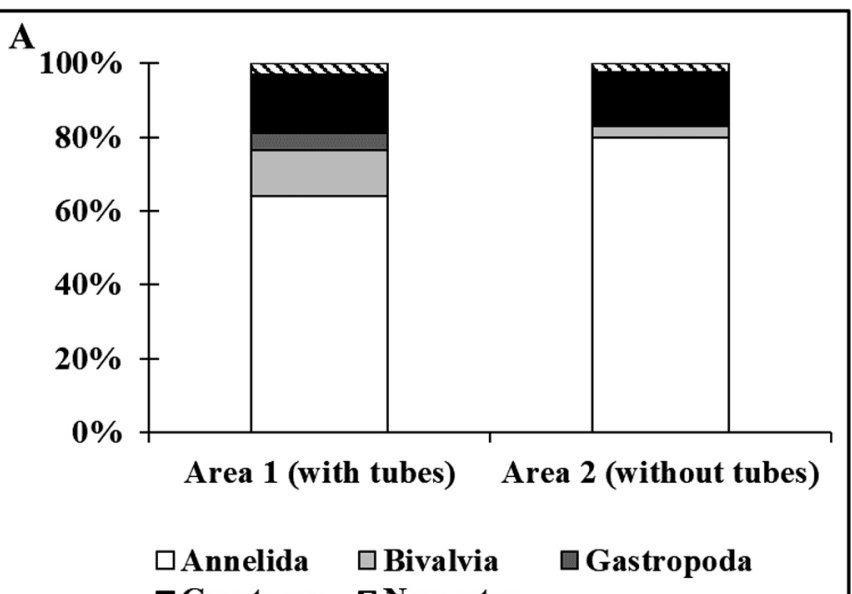

Crustacea $\triangle$ Nemertea

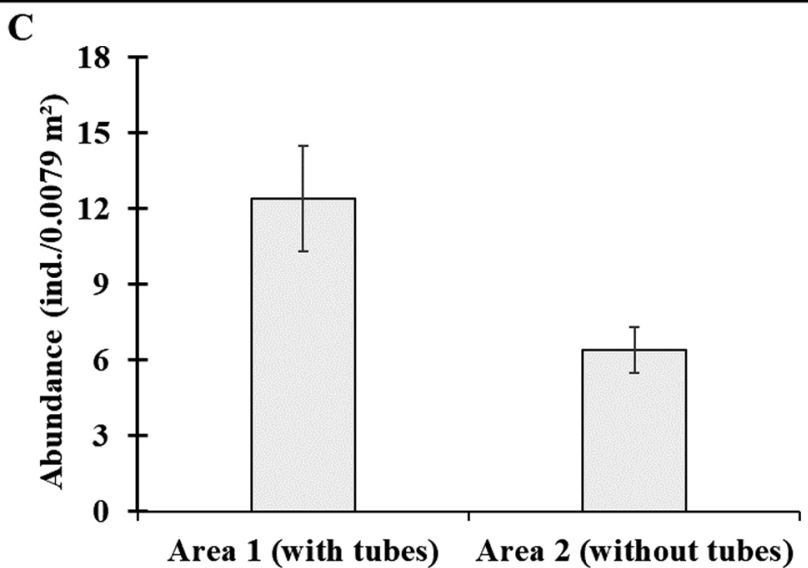

Figure 2. Relative abundance (\%) of taxonomic (A) and feeding groups (B); mean abundance ( \pm standard error) $(C)$ and taxon richness (D) of the macrobenthic fauna of the two sampling plots in the study area.

of suspension/filter feeders occurred at area 1. By contrast, omnivores and predators were more abundant in area 2 (Fig. 2B). The mean macroinvertebrate abundance $\left(F_{1,18}: 4.35 ; p<0.01\right)$ vary significantly among areas, however, no difference was found to richness ( $F_{1,18}: 2.0$; $p=0.18)$. In both cases, the highest values were found in area 1 (Figs. 2C, 2D).

The PCO plots distinguished the macrofauna samples between the two study areas (Fig. 3). Regarding species, axis 1 explained $28.8 \%$ of the variation in the data and was responsible for separating the two areas. The species most correlated with area 1 samples were gastropod Olivela sp. and the polychaetes Capitella spp. and Magelona sp. In contrast, the species most associated with area 2 were the amphipod Phoxocephalidae and polychaetes T. papillata and Glycera sp. Axis 2 also associated samples from area 1 with the bivalve Mytella guyanensis (Lamarck, 1819). Using the trophic functional groups, the PCO had greater explanatory capacity, with axis 1 explained $72.3 \%$ of the variation in the data. The groups best correlated with this axis were predators (most correlated with area 2) and suspension feeder (most correlated with area 1). The PERMANOVA confirmed the spatial configuration of the samples, showing significant differences for species $(F=2.4 ; p=0.021)$ and functional $(F=4.2 ; p=0.027)$ composition between areas.
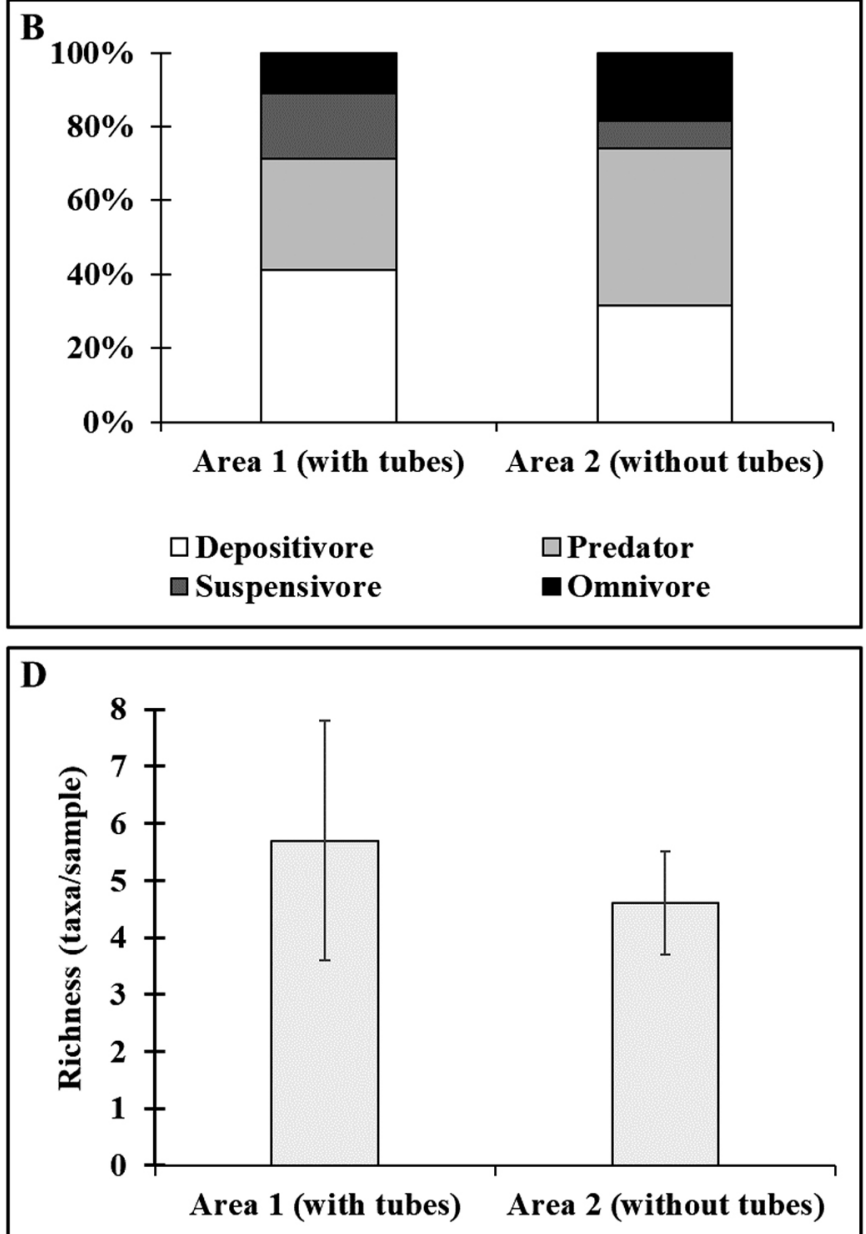

\section{DISCUSSION}

In the study area, the D. cuprea tubes were typically scattered widely in the intertidal zone and the extrapolated density recorded (37.9 ind./ $\mathrm{m}^{2}$ ) was relatively low in comparison with the values at many other intertidal flats (mean densities between 76.7 and 178.3 ind. $/ \mathrm{m}^{2}$ ) (Peckol \& Baxter, 1986; Mangum et al., 1968), but close to that found on beaches (mean 42.5 to 53.8 ind. $/ \mathrm{m}^{2}$ ) (Rosa-Filho et al., 2009; Santos \& Aviz, 2018) and other Amazon soft-bottom habitats (mean 5.3 to 10.6 ind./ $\mathrm{m}^{2}$ ) (Table 2). The species prefers sandy and muddy-sandy substrates, with no records in the essentially muddy sediments (Table 2). Dense aggregations of Diopatra tubes are commonly found in protected intertidal areas, where organic debris are deposited (Bailey-Brock, 1984; Dagli et al., 2005; Thomsen \& McGlathery, 2005). Mangum et al. (1968) found that the population density of $D$. cuprea is related only weakly to the particle size of the substrate but is correlated strongly with current velocity. While higher current speeds may benefit the feeding mode of Diopatra (Mangum et al., 1968), fast currents may harm the physical structure of the tubes, as well as their density. In fact, the low density of $D$. cuprea found on Amazon coastal is probably due to the intense hydrodynamics of the local estuaries (Santos \& Aviz, 2018). Overall, the Amazonian 

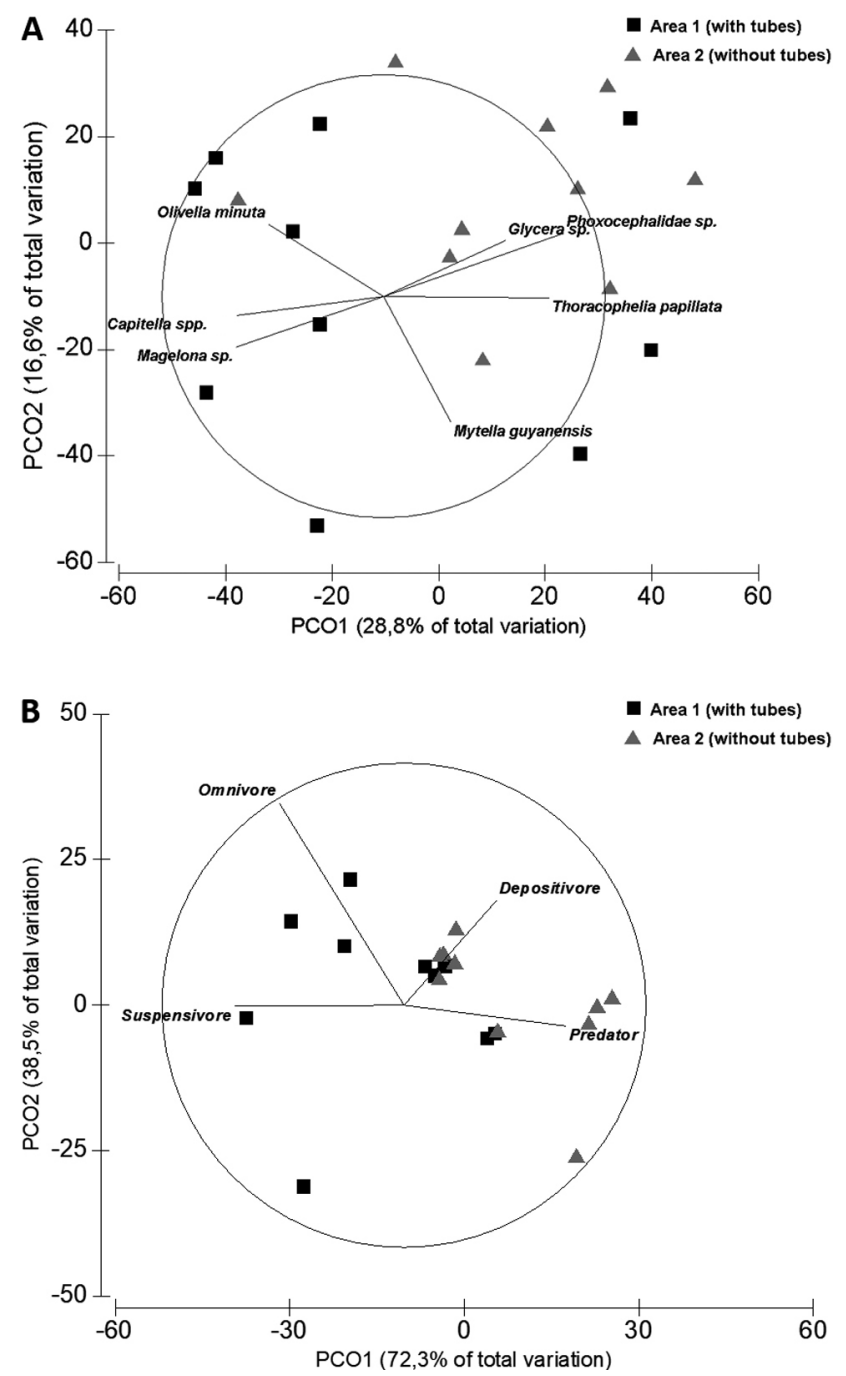

Figure 3. Principal Coordinates Analysis (PCO) of the samples of the macrobenthic fauna considering the (A) taxonomic composition and (B) functional group. The vectors represent species/groups correlating more than $50 \%$ (based on Spearman correlation coefficients) with one of the first two PCO axes.

estuaries are dynamic environments formed by the interaction of waters from the Amazon River and its tributaries with waters of the Atlantic Ocean, and these enormous discharges of water dictate unusual and strong hydrodynamic patterns (Nittrouer \& Demaster, 1996).
While many studies have compared bare sediments with high-density polychaetes tubes aggregations (e.g., Bell \& Coen, 1982a, b; Callaway, 2003; Thomsen et al., 2010), previous studies have shown that even in extremely low density, polychaete tubes can have a strong impact on invertebrate communities in various areas (Callaway, 2006; Thomsen et al., 2011; Santos \& Aviz, 2018). In general, although at a much smaller spatial scale, sparsely distributed tubes increase the complexity and heterogeneity of habitats, thus promoting the establishment of more diverse and abundant macrobenthic communities (Rabaut et al., 2007; Toupoint et al., 2008). Biologic structures commonly influence the composition and organization of benthic communities, facilitate the occurrence of organisms by offering new habitats, increasing protection against abiotic and predation pressures, or contributing to the availability of food (Bouma et al., 2009; Jones et al., 2010).

The taxonomic composition of the macrofauna in the studied area is similar to other estuarine tidal flats tropical as well as to that found in association with $D$. cuprea and other polychaetes tubes (e.g., Lanice conchilega Pallas, 1976) in temperate regions (e.g., Callaway, 2006; Van Hoey et al., 2008; Callaway et al., 2010; Thomsen et al., 2010). The fauna was composed primarily of estuarine and marine taxa and other soft bottoms environments on the Amazon coast, with a dominance of polychaete worms, as well as crustaceans and mollusks as common groups. Also, the composition is similar to the composition found in other soft bottoms environments on the Amazon coast such as sandy beaches (Rosa-Filho et al., 2009, 2011; Santos \& Aviz, 2018, 2020), in muddy environments (Rosa-Filho et al., 2006; Beasley et al., 2010; Braga et al., 2011, 2013; Santos et al., 2020), in addition to the presence of typical species of hard substrates (Morais \& Lee, 2014).

Annelida was the most dominant phylum in both study areas, with polychaetes being the most abundant group. The dominance of annelids on the study areas is probably due to the elongated shape of their bodies, which facilitates burrowing activities in fine sand bottoms (Giangrande \& Gambi, 1998); their high tolerance to environmental stress (Dauvin et al., 2016), which allows them to survive in environments with intense hydrody-

Table 2. Records of Diopatra cuprea observed in soft bottom environments in the Brazilian Amazon Coast.

\begin{tabular}{|c|c|c|c|c|}
\hline Environment & Locality & Coordinates & D. cuprea mean density (ind. $/ \mathrm{m}^{2}$ ) & Reference \\
\hline Tidal flat (muddy-sand bottom) & Piriá River Estuary (Pará, Brazil) & $00^{\circ} 59^{\prime} 26.11^{\prime \prime S}-46^{\circ} 11^{\prime} 08.73^{\prime \prime} \mathrm{W}$ & 37.97 & This study \\
\hline Sandy beach (muddy-sand bottom) & Algodoal Island (Pará, Brazil) & $00^{\circ} 34^{\prime} 45^{\prime \prime} \mathrm{S}-47^{\circ} 32^{\prime} 05^{\prime \prime} \mathrm{W}$ & 53.8 & Santos \& Aviz (2018) \\
\hline Sandy beach (sandy bottom) & Ajuruteua (Pará, Brazil) & $46^{\circ} 35^{\prime} 31.2^{\prime \prime} \mathrm{W}-00^{\circ} 50^{\prime} 19.5^{\prime \prime} \mathrm{S}$ & 42.5 & Rosa-Filho et al. (2009) \\
\hline Sandy beach (sandy bottom) & Algodoal Island (Pará, Brazil) & $00^{\circ} 34^{\prime} 45^{\prime \prime} \mathrm{S}-47^{\circ} 32^{\prime} 05^{\prime \prime} \mathrm{W}$ & - & Rosa-Filho et al. (2011) \\
\hline Sandy beach (muddy-sand bottom) & Algodoal Island (Pará, Brazil) & $00^{\circ} 34^{\prime} 45^{\prime \prime} \mathrm{S}-47^{\circ} 32^{\prime} 05^{\prime \prime} \mathrm{W}$ & - & Santos \& Aviz, 2020 \\
\hline Saltmarsh (muddy-sand bottom) & Algodoal Island (Pará, Brazil) & $00^{\circ} 34^{\prime} 45^{\prime \prime} \mathrm{S}-47^{\circ} 32^{\prime} 05^{\prime \prime} \mathrm{W}$ & 10.6 & Braga et al. $(2011,2013)$ \\
\hline Saltmarsh (muddy-sand bottom) & Canela Island (Pará, Brazil & $00^{\circ} 47^{\prime} 20^{\prime \prime} \mathrm{S}-46^{\circ} 43^{\prime} 63^{\prime \prime} \mathrm{W}$ & - & Braga et al., 2009 \\
\hline Mangrove (sandy-mud bottom) & Curuça Estuary (Pará, Brazil) & $00^{\circ} 43^{\prime} 48^{\prime \prime S}-47^{\circ} 51^{\prime} 06^{\prime \prime} \mathrm{W}$ & 5.3 & Vasconcelos (2006) \\
\hline Mangrove (muddy bottom) & Algodoal Island (Pará, Brazil) & $00^{\circ} 34^{\prime} 45^{\prime \prime} \mathrm{S}-47^{\circ} 32^{\prime} 05^{\prime \prime} \mathrm{W}$ & - & Monteiro (2009) \\
\hline Mangrove (muddy bottom) & Caeté Estuary (Pará, Brazil) & $00^{\circ} 50^{\prime} 19.5^{\prime \prime} \mathrm{S}-46^{\circ} 38^{\prime} 14.9^{\prime \prime} \mathrm{W}$ & - & Rosa-Filho et al. (2006) \\
\hline Mangrove (muddy bottom) & Caeté Estuary (Pará, Brazil) & $00^{\circ} 50^{\prime} 19.5^{\prime \prime} \mathrm{S}-46^{\circ} 38^{\prime} 14.9^{\prime \prime} \mathrm{W}$ & - & Beasley et al. (2010) \\
\hline Mangrove (muddy bottom) & São Luis Island (Maranhão, Brazil) & $02^{\circ} 37^{\prime} 27^{\prime \prime} \mathrm{S}-44^{\circ} 20^{\prime} 36^{\prime \prime} \mathrm{W}$ & - & Oliveira \& Mochel (1999) \\
\hline Mangrove (muddy bottom) & Maracá Island (Amapá, Brazil) & $01^{\circ} 50^{\prime} 54^{\prime \prime} \mathrm{N}-50^{\circ} 12^{\prime} 00^{\prime \prime} \mathrm{W}$ & - & Fernandes (2003) \\
\hline
\end{tabular}


namics (Omena \& Amaral, 2003; Purschke, 1981); and their diversity of feeding habits, which allows them to explore a wide range of food resources (Fauchald \& Jumars, 1979; Jumars et al., 2015). Also, this dominance is mainly related to the great abundance of Magelona sp. at area 1 and Nephtys simoni at area 2. The magelonids are common in the muddy sand substrates of intertidal zones and continental shelves (Hartman, 1971; Fauchald \& Jumars, 1979). On the other hand, N. simoni is commonly found on sandy areas being present in great abundance in areas with granulometry ranging from medium to fine sand (Lana, et al., 1996; Rosa-Filho et al., 2011).

While there are obvious limitations to the comparison of regions and/or habitats, the total number of taxa (21) recorded in the estuary of the Piriá river was lower than that recorded in most studies on the Amazon coast (Table 2). In the present study, this lower richness probably results from two factors: (1) the low spatial and temporal effort of sampling; and (2) the greater instability of the tidal flat, when compared to more protected and/or vegetated environments, such as mangroves and saltmarsh. Tidal flats are highly dynamic environments, with sediments in constant motion through several processes (e.g., transportation, deposition, and erosion), depending on the hydrodynamic characteristics (e.g., tide, waves, and wind) of the local area (Black et al., 2002).

In the present study, although there was no significant increase in richness in the area with tubes, changes in abundance and composition and trophic groups were observed. Although the sedimentary composition of the sediment could not be evaluated in this study, the presence of $D$. cuprea tubes has been associated with an increase in fine sediment, due to reducing the velocity of the near-bottom flow and increase in the deposition (Eckman et al., 1981; Friederichs et al., 2000; Bolam \& Fernandes, 2003; Callaway, 2006). Fine, organically rich muds tend to contain more burrowing deposit feeders, whereas coarser sandy sediments typically harbor more mobile animals and predators (Pearson \& Rosenberg, 1978). Although, in general, the assemblages of the study area were dominated by deposit feeders, the deposit feeders and filter-feeders were more representatives in area 1 (with tubes), while predators and omnivores in area 2 (without tubes).

The higher abundance of deposit feeders in area 1 was related principally to polychaetes Magelona sp., Capitella spp. and Mediomastus sp. Both magelonids and capitellids are deposit feeders, of surface and sub-surface, respectively, which are common in the muddy sand substrates of intertidal zones and continental shelves (Hartman, 1971; Fauchald \& Jumars, 1979). On the other hand, mollusk bivalves were the main responsible for the greater abundance of filter-feeders in area 1. These organisms were represented primarily by species (e.g., Sphenia sp. and Mytella guyanensis) not normally found on soft bottoms, but on hard substrates, such as rocks, mangrove roots, and other biogenic materials, and in the present study, they were found attached to the $D$. $c u$ prea tubes. Additionally, the gastropod Olivella minuta (Link, 1807) occurred exclusively in the area with tubes and was the main responsible for the abundance of omnivores in this area. This gastropod is commonly found in protected environments with finer sediments (Viana et al., 2005) and, although in small scale, in the present study these characteristics would probably be found near the $D$. cuprea. In area 2 , higher predator abundance was related principally to Nephtys simoni, which prefers fine to medium sand (Lana, 1986; Rosa-Filho et al., 2011).

\section{CONCLUSION}

Although the present study presents a small spatial scale and we did not test for temporal effects, its results are consistent with those of previous research, which found changes in the composition of the benthic macrofauna in areas with and without polychaete tubes, even though $D$. cuprea was sparsely distributed on the study area. This conclusion would be reinforced by a broader sampling, which would include a larger number of tubes and areas, larger-scale effects, as well the sedimentary and hydrodynamic parameters. The present findings add knowledge about the presence of the bioconstructor in other types of habitats in the Amazon.

\section{ACKNOWLEDGMENTS}

We are grateful to Roseanne Figueira for her help in the field work and Bruna Melo for her help processing the samples. Thanks also to the anonymous reviewers for their comments, which helped us to improve the manuscript.

\section{AUTHORS' CONTRIBUTIONS}

Santos, T.M.T.: research conceptualization, data collection, data analysis and interpretation, writing - original draft; writing - review \& editing. Aviz, D.: research conceptualization, data analysis and interpretation, writing - original draft; writing - review \& editing. Funding Declaration: Authors received no specific funding for this work. Conflict/Declaration of Interest: None. Ethics and Permits: All research pertaining to this article did not require any research permits.

\section{REFERENCES}

Amaral, A.C.Z. \& Nonato, E.F. 1996. Chave para identificação dos Anelídeos Poliquetas da costa brasileira; revista e ampliada. 2. ed. Campinas, Editora da UNICAMP. 90p.

Amaral, A.C.Z.; Rizzo, A.E. Arruda, E.P. 2006. Manual de identificação dos invertebrados marinhos da Região Sudeste-Sul do Brasil. São Paulo, EdUSP. v. 1.

Ataide, M.B.; Venekey, V.; Rosa-Filho, J.S. \& dos Santos, P.J.P. 2014. Sandy reefs of Sabellaria wilsoni (Polychaeta: Sabellariidae) as ecosystem engineers for meiofauna in the Amazon coastal region, Brazil. Marine Biodiversity, 44(3): 403-413. 
Aviz, D.; da Silva, R.F. \& Rosa-Filho, J.S. 2018. Sabellaria wilsoni (Polychaeta: Sabellariidae): an ecosystem engineer and promoter of zoobenthos diversity in the Brazilian Amazon coast. Journal of the Marine Biological Association of the United Kingdom, 99(5):1099-1109. DOI

Aviz, D.; Santos, C.R.M. \& Rosa-Filho, J.S. 2021. Sabellariid (Polychaeta: Annelida) reefs as nursery ground for the hermit crab (Randall, 1840) on the Amazonian coast of Brazil. Marine Biology Research, 17(1):21. D0I

Baia, E.; Rollnic, M. \& Venekey, V. 2021. Seasonality of pluviosity and saline intrusion drive meiofauna and nematodes on an Amazon freshwateroligohaline beach. Journal of Sea Research, 170: 102022.

Bailey-Brock, J. 1984. Ecology of the tube-building polychaete Diopatra leuckarti Kinberg, 1865 (Onuphidae) in Hawaii: community structure, and sediment stabilizing properties. Zoological Journal of Linnean Society, 80(2-3): 191-199.

Beasley, C.R.; Fernandes, M.E.B.; Figueira, E.A.G.; Sampaio, D.S.; Melo, K.R. \& Barros, R.S. 2010. Mangrove infauna and sessile epifauna. In: Saint-Paul, U. \& Schneider, H. (Eds.). Mangrove dynamics and management in North Brazil. Berlin, Springer. p. 109-123.

Bell, S.S. 1985. Habitat complexity of polychaete tube-caps: influence of architecture dynamics of meioepibenthic assemblage. Journal of Marine Research, 43(3): 647-671.

Bell, S.S. \& Coen, L.D. 1982a. Investigations on epibenthic meiofauna. II. Influence of microhabitat and macroalgae on abundance of small invertebrates of Diopatra cuprea tube-caps in Virginia. Journal of Experimental Marine and Ecology, 61(2): 175-188.

Bell, S.S. \& Coen, L.D. 1982b. Investigations on epibenthic meiofauna. I. Abundances on and repopulation of the tube caps of Diopatra cuprea (Polychaeta: Onuphidae). Marine Biology, 67(3): 303-309.

Bell, S.S. \& Woodin, S.A. 1984. Community unity: experimental evidence for meiofauna and macrofauna. Journal of Marine Research, 42(3): 605-632.

Black, K.S.; Tolhurst, T.J.S.; Hagerthey, E. \& Paterson, D.M. 2002. Working with natural cohesive sediments. Journal of Hydraulic Engineering, 128(1): 2-8.

Bolam, S.G. \& Fernandes, T.F. 2003. Dense aggregations of tubebuilding polychaetes: response to small-scale disturbances. Journal of Experimental Marine Biology and Ecology, 269: 197-222.

Bosc, L.A.G. 1802. Histoire naturelle des vers contenant leur description et leurs moeurs, avec figures dessinées d'après nature. Paris, De l'imprimerie de Guilleminet; a chez Deterville. v. 1, 324p.

Bouma, T.J.; Olenin, S.; Reise, K. \& Ysebaert, T. 2009. Ecosystem engineering and biodiversity in coastal sediments: posing hypotheses. Helgoland Marine Research, 63(1): 95-106.

Braga, C.F.; Beasley, C.R. \& Isaac, V.J. 2009. Effects of plant cover on the macrofauna of Spartina marshes in northern Brazil. Brazilian Archives of Biology and Technology, 52(6): 1409-1420.

Braga, C.F.; Monteiro, V.F.; Rosa-Filho, J.S. \& Beasley, C.R. 2011. Benthic macroinfaunal assemblages associated with Amazonian saltmarshes. Wetland Ecology and Management, 19(3): 257-272.

Braga, C.F.; Silva, R.F.; Rosa-Filho, J.S. \& Beasley, C.R. 2013. Spatio-temporal changes in macroinfaunal assemblages of tropical saltmarshes, northern Brazil. Pan-American Journal of Aquatic Sciences, 8(3): 282-298.

Callaway, R. 2003. Long-term effects of imitation polychaete tubes on benthic fauna: they anchor Mytilus edulis (L.) banks. Journal of Experimental Marine Biology and Ecology, 283(1-2): 115-132.

Callaway, R. 2006. Tube worms promote community change. Marine Ecology Progressive Series, 30: 849-860.

Callaway, R.; Desroy, N.; Dubois, S.F.; Fournier, J.; Frost, M.; Godet, L.; Hendrick, V.J. \& Rabaut, M. 2010. Ephemeral bio-engineers or reefbuilding polychaetes: how stable are aggregations of the tube worm Lanice conchilega (Pallas 1766). Integrative and Compararrive Biology, 50(2): 237-250.
Dagli, E.; Ergen, Z.\& Çinar, M.E. 2005. One-year observation on the population structure of Diopatra neapolitana Delle Chiaje (Polychaeta Onuphidae) in Izmir Bay (Aegean Sea, eastern Mediterranean). Marine Ecology, 26(3-4): 265-272.

Danin, A.P.; Pombo, M.; Martinelli-Lemos, J.M.; Santos, C.R.M.; Aviz, D. \& Petracco, M. 2020. Population ecology of the hermit crab Clibanarius symmetricus (Anomura: Diogenidae) on an exposed beach of the Brazilian Amazon coast. Regional Studies in Marine Science, 33: 100944.

Dauby, P.; Scailteur, Y. \& De Broyer, C. 2001. Trophic diversity within the eastern Weddell Sea amphipod community. Hydrobiologia, 443(1-3): 69-86.

Dauer, D.M.; Tourtelotte, G.H. \& Ewing, R.M. 1982. Oyster shells and artificial worm tubes: the role of refuge in structuring benthic communities of the lower Chesapeake Bay. Internationale Revue der Gesamten Hidrobiologie, 67(5): 661-677.

Dauvin, J.C.; Andrade, H.; de-la-Ossa-Carreteroe, J.A.; Del-Pilar-Rusoe, Y. \& Rieraf, R. 2016. Polychaete/amphipod ratios: An approach to validating simple benthic indicators. Ecological Indicators, 63: 89-99.

De Broyer, C.; Chapelle, G.; Duchesne, P.A.; Munn, F.; Nyssen, Y.; Scailteur, F.; Van Roozendalel \& Dauby, P. 2003. Structural and ecofunctional biodiversity of the amphipod crustacean benthic taxocoenoses in Southern Ocean. In: Scientific Support plan for a Sustainable Development Policy SPSD 1: Belgian Scientifc Research Programme on the Antarctic, Phase 4 (1997-2001). Scientific Results, 1: Marine biota and Global Change. Brussels, Institut Royal des Sciences Naturelles de Belgique. Laboratoire de Carcinologie. 61p.

de León-González, J.A.; Bastida-Zavala, J.R.; Carrera-Parra, L.F.; GarcíaGarza, M.E.; Peña-Rivera, A.; Salazar-Vallejo, S.I. \& Solís-Weiss, V. 2009. Poliquetos (Annelida: Polychaeta) de México y América Tropical. Nuevo León, México, Universidad Autónoma de Nuevo León.

Dittmar, T. \& Lara, R.J. 2001. Driving forces behind nutrient and organic matter dynamics in a mangrove tidal creek in North Brazil. Estuarine, Coastal and Shelf Science, 52(2): 249-259.

Dubois, S.; Commito, J.A.; Olivier, F. \& Retière, C. 2006. Effects of epibionts on Sabellaria alveolata (L.) biogenic reefs and their associated fauna in the Bay of Mont Saint-Michel. Estuarine, Coastal and Shelf Science, 68(3-4): 635-646.

Dubois, S.; Retière, C. \& Olivier, F. 2002. Biodiversity associated with Sabellaria alveolata (Polychaeta: Sabellariidae) reefs: effects of human disturbances. Journal of Marine Biology Association of United Kingdom, 82(5): 817-826.

Dyer, K.R.; Christe, M.C. \& Wright, E.W. 2000. The classification of intertidal mudfats. Continental Shelf Research, 20(10-11): 1039-1060.

Eckman, J.E.; Nowell, A.R.M. \& Jumars, P.A. 1981. Sediment destabilization by animal tubes. Journal of Marine Research, 39(2): 361-374.

Fauchald, K. \& Jumars, P.A. 1979. The diet of worms: a study of polychaete feeding guilds. Oceanography and Marine Biology, 17: 193-284.

Fernandes, M.E.B. 2003. Macroendofauna bêntica de substrato móvel. In: Fernandes, M.E.B. (Ed.). Os Manguezais da Costa Norte Brasileira. São Luís, Fundação Rio Bacanga. p. 87-103.

Fournier, J. 2010. Bibliography of coastal Worm-Reefs species of the world (1950-2010). Dinard, CNRS/MNHN.

Friederichs, M.; Graf, G. \& Springer, B. 2000. Skimming flow induced over a simulated polychaete tube lawn at low population densities. Marine Ecology Progressive Series, 192: 219-228.

Gao, S. 2019. Geomorphology and Sedimentology of Tidal Flats. In: Coastal Wetlands. 2. ed. Elsevier. p. 359-381. DOI

Giangrande, A. \& Gambi, M.C. 1998. Metamerism and life-style within polychaetes: Morpho-functional aspects and evolutionary implications. Italian Journal of Zoology, 65(1): 39-50. 
Giangrande, A.; Gambi, M.C. \& Gravina, M.F. 2020. Polychaetes as Habitat Former: Structure and Function. In: Perspectives on the Marine Animal Forests of the World. Cham, Springer. p. 219-237.

Guilherme, B.C.; Silva, G.B.; El-Deir, A.C.A. \& Santos, P.J.P. 2011. Meiofauna associada ao tubo de Diopatra cuprea Bosc 1902 (Polychaeta: Onuphidae). Revista Brasileira de Zoologia, 5: 37-52.

Hartman, 0. 1971. Abyssal polychaetous annelids from the Mozambique Basin off Southeast Africa, with a compendium of abyssal polychaetous annelids from world-wide areas. Journal of the Fisheries Research Board of Canada, 28(10): 311-389.

Instituto Chico Mendes de Conservação da Biodiversidade (ICMBio). 2010. Plano de Manejo da Reserva Extrativista Marinha Gurupi-Piriá. [Não publicado].

Jones, A.G.; Dubois, S.F.; Desroy, N. \& Fournier, J. 2018. Interplay between abiotic factors and species assemblages mediated by the ecosystem engineer Sabellaria alveolata (Annelida: Polychaeta). Estuarine, Coastal and Shelf Science, 200: 1-18.

Jones, C.G.; Gutiérrez, J.L.; Byers, J.E.; Crooks, J.A.; Lambrinos, J.G. \& Talley, T.S. 2010. A framework for understanding physical ecosystem engineering by organisms. Oikos, 119(12): 1862-1869.

Jones, C.G.; Lawton, J.H. \& Shachak, M. 1994. Organisms as ecosystem engineers. Oikos, 69(3): 373-386.

Jumars, P.A. \& Nowell, A.R.M. 1984. Fluid and sediment dynamic effect on marine benthic community structure. American Zoology, 24: 44-55.

Jumars, P.A.; Dorgan, K.M. \& Lindsay, S.M. 2015. Diet of Worms Emended: An Update of Polychaete Feeding Guilds. Annual Review of Marine Science, 7(1): 497-520.

Kjerfve, B. \& Lacerda, L.D. 1993. Mangroves of Brazil. In: Lacerda, L.D. (Ed.). Conservation and sustainable utilization of mangrove forest in Latin America and Africa regions. Part I - Latin America. International Society for Mangrove Ecosystems. Technical Report No. 2. ITTO/ISME, Okinawa, 272.

Lamarck, J.B.M. 1819. Histoire naturelle des animaux sans vertèbres. Paris. v. 6, pt. 1,343p.

Lana, P.C. 1986. Nephtyidae (Annelida; Polychaeta) do litoral do estado do Paraná (Brasil). Neritica, 1: 135-155.

Lane-Medeiros, L.; Puppin-Gonçalves, C.T.; da Rocha, M.A.L.; Alencar, C.E.R.D. \& Freire, F.A.M. 2021. Macrocrustaceans associated with reefs of Phragmatopoma caudata Krøyer in Mörch, 1863 (Polychaeta: Sabellariidae) and rocky shore in the Northeastern Brazil. Papéis Avulsos de Zoologia, 61(19): e20216119.

Macdonald, T.A.; Burd, B.J.; Macdonald, V.I. \& Roodselaar, A.V. 2010. Taxonomic and feeding guild classification for the marine benthic macroinvertebrates of the Strait of Georgia, British Columbia. Canadian Technical Report of Fisheries and Aquatic Sciences, 2874: 1-63.

Mangum, C.P.; Santos, L.S. \& Rhodes, W.R. 1968. Distribution and feeding in the Onuphid polychaete, Diopatra cuprea (Bosc). Marine Biology, 2: 33-40.

Martorano, L.G.; Pereira, L.C.; César, E.G.M. \& Pereira, I.C.B. 1993. Estudos Climáticos do Estado do Pará: Classificação Climática (Köppen) e Deficiência Hídrica (Thornthwaite, Mather). Belém, SUDAM/EMBRAPA/SNLCS.

Matsui, G.Y.; Ringelberg, D.B. \& Lovell, C.R. 2004. Sulfate-reducing bacteria in tubes constructed by the marine infaunal polychaete Diopatra cuprea. Applied and Environmental Microbiology, 70(12): 7053-7065.

Melo, G.A.S. 1999. Manual de identificação dos Crustacea Decapoda do litoral brasileiro: Anomura, Thalassinidea, Palinuridea e Astacidea. São Paulo, Plêiade. 556p.

Monteiro, V.F. 2009. Eficiência de diferentes abordagens metodológicas e caracterização das associações macrobentônicas estuarinas da zona costeira amazônica. Belém, Universidade Federal do Pará. 96p.

Moraes, B.C.; Costa, J.M.N.; Costa, A.C.L. \& Costa, M.H. 2005. Variação espacial e temporal da precipitacão no Estado do Pará. Acta Amazonica, 35(2): 207-214.
Morais, G.C. \& Lee, J.T. 2014. Intertidal benthic macrofauna of rare rocky fragments in the Amazon region. Revista de Biologia Tropical, 62: 69-86.

Myers, A.C. 1972. Tube-worm-sediment relationships of Diopatra cuprea (Polychaeta: Onuphidae). Marine Biology, 17(4): 350-356.

Nittrouer, C.A. \& Demaster, D.J. 1996. Oceanography of the Amazon continental shelf. Continental Shelf Research, 16:553-573.

Oliveira, M. \& Mochel, F.R. 1999. Macroendofauna bêntica de substratos móveis de um manguezal sob impacto das atividades humanas no sudoeste da llha de São Luís, Maranhão, Brasil. Boletim do Laboratório de Hidrobiologia, 2: 75-93.

Omena, E. \& Amaral, A. 2003. Sandy beach morphodynamic and the Polychaete fauna in Southeast Brazil. Journal of Coastal Research, 35: 431-439.

Pearson, T.H. \& Rosenberg, R. 1978. Macrobenthic succession in relation to organic enrichment and pollution of the marine environment. Oceanography and Marine Biology, 16: 219-311.

Peckol, P. \& Baxter, D. 1986. Population dynamics of the onuphid polychaete Diopatra cuprea (Bose) along a tidal exposure gradient. Estuarine Coastal and Shelf Science, 22(3): 371-377.

Pereira, L.C.C.; Sozinho da Silva, N.I.; da Costa, R.M.; Asp, N.E.; da Costa, K.G. \& Vila-Concejo, A. 2012. Seasonal changes in oceanographic processes at na equatorial macrotidal beach in northern Brazil. Continental Shelf Research, 43: 95-106.

Perkins, T.H. 1980. Review of the species previously referred to Ceratonereis mirabilis, and descriptions of new species of Ceratonereis, Nephtys, and Goniada (Polychaeta). Proceedings of the Biological Society of Washington, 93(1): 1-49.

Phillips, T.M. \& Lovell, C.R. 1999. Distribution of total and active bacteria in biofilms lining tubes of the onuphid polychaete Diopatra cuprea. Marine Ecology Progressive Series, 183: 169-178.

Purschke, G. 1981. Tolerance to freezing and supercooling of interstitial turbellaria and polychaeta from a sandy tidal beach of the island of Sylt (North Sea). Marine Biology, 63(3): 257-267.

Rabaut, M.; Guilini, K.; Van Hoey, G.; Magda, V. \& Degraer, S. 2007. A bioengineered soft-bottom environment: the impact of Lanice conchilega on the benthic species-specific densities and community structure. Estuarine Coastal and Shelf Science, 75(4): 525-536.

Rios, E.C. 2009. Compendium of Brazilian sea shells. Rio Grande,: Ed. Evangraf. $676 p$.

Rosa-Filho, J.S.; Pereira, L.C.C.; Aviz, D.; Braga, C.F.; Monteiro, M.C.; da Costa, R.A.M.; Asp, N.E. \& Beasley, C.R. 2018. Benthic estuarine assemblages of the Brazilian North Coast (Amazonia Ecoregion). In: Lana, P.D.C. \& Bernardino, A.F. (Eds.). Brazilian Estuaries: A Benthic Perspective. Cham, Springer International Publishing. p. 39-74.

Rosa-Filho, J.S.; Almeida, M.F. \& Aviz, D.E. 2009. Spatial and temporal changes in the benthic fauna of a macrotidal Amazon sandy beach, Ajuruteua, Brazil. Journal of Coastal Research, 56 (Special issue): 1796-1780.

Rosa-Filho, J.S.; Busman, D.V.; Viana, A.P.; Gregório, A.M. \& Oliveira, D.M. 2006. Macrofauna bentônica de zonas entre-marés não vegetadas do estuário do rio Caeté (Bragança-PA). Boletim do Museu Paraense Emilio Goeldi, Ciencias Naturais, 2(3): 109-121.

Rosa-Filho, J.S.; Gomes, T.P.; Almeida, M.F. \& Silva, R.F. 2011. Benthic fauna of macrotidal sandy beaches along a small-scale morphodynamic gradient on the Amazon coast (Algodoal Island, Brazil). Journal of Coast Research, 64: 435-439.

Santos, C.S.G.; Nonato, E.F. \& Petersen, M.E. 2004. Two new species of Opheliidae (Annelida: Polychaeta): Euzonus papillatus sp. n. from a northeastern Brazilian sandy beach and Euzonus mammillatus sp. n. from the continental shelf of southeastern Brazil. Zootaxa, 478: 31:1-12. DOI

Santos, T.M.T. \& Aviz, D. 2018. Macrobenthic fauna associated with Diopatra cuprea (Onuphidae: Polychaeta) tubes on a macrotidal sandy beach of 
the Brazilian Amazon Coast. Journal of Marine Biology Association of United Kingdom, 99(4): 751-759.

Santos, T.M.T. \& Aviz, D. 2020. Effects of a fish weir on the structure of the macrobenthic community of a tropical sandy beach on the Amazon coast. Journal of Marine Biology Association of United Kingdom, 100(2): 211-219.

Santos, T.M.T.; Rabelo, D.M.L.; Beasley, C.R. \& Braga, C.F. 2020. Vertical distribution of macrobenthic community of tropical saltmarshes on the Amazon coast. Regional Studies in Marine Science, 40: 101536. D0I

Souza-Filho, P.W.M.; Lessa, G.C.; Cohen, M.C.L.; Costa, F.R. \& Lara, R.F. 2009. The subsiding macrotidal barrier estuarine system of the Eastern Amazon coast, northern Brazil. Lectures Notes in Earth Sciences, 107: 347-375.

Toupoint, N.; Godet, L.; Fournier, J.; Retiere, C. \& Olivier, F. 2008. Does Manila clam cultivation affect habitats of the engineer species Lanice conchilega (Pallas, 1766)? Marine Pollution Bulletin, 56(8): 1429-1438.

Thomsen, M.S. 2004. Species, thallus size and substrate determine macroalgal break force and break location in a low-energy soft-bottom lagoon. Aquatic Botany, 80: 153-161.

Thomsen, M.S. \& McGlathery, K.J. 2005. Facilitation of macroalgae by the sedimentary tube forming polychaete Diopatra cuprea. Estuarine Coastal and Shelf Science, 62: 63-73.

Thomsen, M.S.; McGlathery, K.J.; Schwarzschild, A. \& Silliman, B.R. 2009. Distribution and ecological role of the non-native macroalga Gracilaria vermiculophylla in Virginia salt marshes. Biological Invasions, 11(10): 2303-2316.

Thomsen, M.S.; Muth, M.F.\& McGlathery, K.J. 2011. Tube-forming polychaetes enhance invertebrate diversity and abundance in sandy sediments of Mozambique Africa. African Journal of Marine Sciences, 33(2): 327-332.
Thomsen, M.S.; Wernberg, T.; Altieri, A.; Tuya, F.; Gulbransen, D.; McGlathery, K.; Holmer, M. \& Silliman, B.R. 2010. Habitat cascades: the conceptual context and global relevance of facilitation cascades via habitat formation and modification. Integrative and Comparative Biology, 50(2): 158-175.

Van Hoey, G.; Guilini, K.; Rabaut, M.; Vincx, M. \& Degraer, S. 2008. Ecological implications of the presence of the tube-building polychaete Lanice conchilega on soft-bottom benthic ecosystems. Marine Biology, 154(6): 1009-1019.

Vasconcelos, T.R. 2006. Respostas às variações espaço temporais das comunidades macrobêntonicas de fundos inconsolidados do estuário de Curuçá (Curuçá-PA). Belém, Universidade Federal do Pará. 42p.

Venekey, V.; Melo, T.P.G. \& Rosa-Filho, J.S. 2019. Effects of seasonal fluctuation of amazon river discharge on the spatial and temporal changes of meiofauna and nematodes in the amazonian coast. Estuarine Coastal and Shelf Science, 227: 106330.

Viana, M.G.; Rocha-Barreira, C.A. \& Grossi Hijo, C.A. 2005. Macrofauna bentônica da faixa entremarés e zona de arrebentação da praia de Paracuru (Ceará-Brasil). Brazilian Journal of Aquatic Science and Technology, 9(1): 75-82.

Warton, D.I.; Duursma, R.A.; Falster, D.S. \& Taskinen, S. 2012. SMATR 3 - an R package for estimation and inferenceabout allometric lines. Methods in Ecology and Evolution, 3: 257-259.

Woodin, S.A. 1978. Refuges disturbance and community structure: a marine soft-bottom example. Ecology, 59(2): 274-284. 